IMEJ: Islamic Management and Empowerment Journal

Volume 2, Number 2, Desember 2020. p. 203-214

P-ISSN:2685-953X; e-ISSN:2686-0317

DOI: $10.18326 /$ imej.v2i2.203-214

website: http://e-journal.iainsalatiga.ac.id/index.php/imej

\title{
Strategi Pengelolaan SDM Lembaga Bisnis Syariah melalui Kinerja Karyawan
}

\section{Saifudin ${ }^{1}$}

Fakultas Ekonomi dan Bisnis Islam IAIN Salatiga

1saifudin@iainsalatiga.ac.id

\section{Dyah Kusumawati ${ }^{2}$}

Fakultas Ekonomi dan Ilmu Sosial UNISFAT Demak

22dyahk291175@gmail.com

\begin{abstract}
The purpose of this paper is to determine the factors that influence employee performance in Islamic banking human resource (HR) management practices. Testing the regression model using SPSS. The independent variables in this study are training, empowerment, service orientation, and rewards which are tested for their effects on employee performance. The results showed that training and empowerment had no effect on employee performance, while service orientation and reward had a positive and significant effect on employee performance.
\end{abstract}

Keywords: training; empowerment; service orientation; rewards; employee performance

\section{Abstrak}

Tujuan paper ini adalah untuk mengetahui faktor-faktor yang mempengaruhi kinerja karyawan dalam praktik pengelolaan sumber daya manusia (SDM) perbankan syariah. Pengujian model regresi menggunakan SPSS. Variabel independen dalam penelitian ini adalah pelatihan, pemberdayaan, orientasi pelayanan, dan penghargaan yang diuji pengaruhnya terhadap kinerja karyawan. Hasil penelitian menunjukkan bahwa pelatihan dan pemberdayaan tidak berpengaruh terhadap kinerja karyawan, sedangkan orientasi pelayanan dan penghargaan berpengaruh positif dan signifikan terhadap kinerja karyawan.

Kata Kunci: pelatihan; pemberdayaan; orientasi pelayanan; penghargaan; kinerja karyawan 


\section{Pendahuluan}

Kinerja karyawan merupakan hal paling pokok dalam keberlangsungan hidup lembaga bisnis syariah, karena tanpa kinerja karyawan yang baik, perusahaan akan mengalami kerugian. Kinerja karyawan dapat terbentuk dengan baik jika lembaga bisnis syariah memperhatikan kebutuhan-kebutuhan karyawan itu sendiri. Kebutuhan karyawan dalam kantor tentu sangat banyak, tetapi setidaknya ada beberapa hal pokok yang perlu diperhatikan, seperti pelatihan, pemberdayaan, orientasi pelayanan dan penghargaan. Jika salah satu dari prediktor kinerja karyawan tidak terpenuhi maka akan menimbulkan masalah bagi lembaga bisnis syariah.

Permasalahan kinerja karyawan tidak hanya terjadi pada lembaga bisnis konvensional, tetapi pada kenyataannya juga terjadi pada lembaga bisnis syariah seperti perbankan syariah. Kasus kinerja karyawan yang amoral pernah dialami oleh Bank Syariah Mandiri (BSM) Kantor Kompleks Perta Arun Gas, Lhokseumawe (Masriadi, 2019). Kasus ini bermula ketika karyawan BSM sedang terlilit hutang yang kemudian memunculkan niat karyawan mencuri Rp 19 juta di kantornya sendiri. Fenomena ini tidak mustahil terjadi ketika pelatihan, pemberdayaan, orientasi pelayanan serta penghargaan tidak dapat dipenuhi oleh lembaga bisnis syariah pada karyawannya.

Dari kasus di atas jelas bahwa betapa pentingnya pengelolaan sumber daya manusia dalam segala segi kehidupan terutama yang berkaitan erat dengan kinerja karyawan dalam lembaga bisnis syariah sebab apabila sebuah lembaga bisnis syariah memiliki manajemen sumber daya manusia yang baik, kinerja karyawan yang baik maka operasional perusahaan akan berjalan dengan baik dan lancar juga. Tujuan, visi dan misi lembaga bisnis syariah akan terwujud karena mereka memiliki sumber daya manusia yang berintegritas tinggi, profesional dalam bidangnya, dan memahami nilai-nilai moral yang diaplikasikan di tempat mereka bekerja

Pada saat ini sudah banyak dilakukan penelitian-penelitian tentang pengelolaan sumber daya manusia. Penelitian tentang peran pelatihan dalam meningkatkan kinerja karyawan telah dilakukan oleh peneliti sebelumya, seperti penelitian yang telah dilakukan oleh Adhinugroho (2015), Triasmoko, dkk., (2014) yang membuktikan bahwa pelatihan 
berpengaruh positif signifikan terhadap kinerja karyawan. Berbeda halnya dengan penelitian yang dilakukan oleh Felisita (2016), yang menunjukkan hasil sebaliknya, yaitu pelatihan tidak memiliki pengaruh positif terhadap kinerja karyawan.

Demikian juga dengan penelitian tentang peran penghargaan dalam meningkatkan kinerja karyawan juga telah dilakukan, seperti halnya penelitian yang telah dilakukan oleh Adhinugroho (2015), Hukubun (2013) yang membuktikan bahwa penghargaan berpengaruh positif signifikan terhadap kinerja karyawan. Berbeda halnya dengan penelitian yang dilakukan oleh Felisita (2016), menunjukkan hasil sebaliknya, bahwa penghargaan yang dalam hal ini disebutkan sebagai kompensasi, ternyata tidak memiliki pengaruh positif terhadap kinerja karyawan.

Melihat beberapa fenomena yang terjadi dan perbedaan hasil penelitian di atas, maka penelitian tentang kinerja karyawan dirasa perlu dilakukan lebih mendalam, khususnya di lembaga bisnis syariah.

Beberapa penelitian terkait dengan pengelolaan SDM diantaranya adalah Penelitian Adhinugroho (2015), Triasmoko, dkk., (2014) juga menunjukkan bahwa pelatihan mempengaruhi kinerja karyawan, maka dapat dibangun hipotesis pertama H1o: Tidak terdapat pengaruh pada pelatihan terhadap kinerja karyawan. H1a: Terdapat pengaruh pada pelatihan terhadap kinerja karyawan.

Selanjutnya penelitian Adhinugroho (2015), Suryadewi, dkk., (2014) juga menunjukkan bahwa pemberdayaan mempengaruhi kinerja karyawan, maka dapat dibangun hipotesis kedua H2o: Tidak terdapat pengaruh pada pemberdayaan terhadap kinerja karyawan. H2a: Terdapat pengaruh pada pemberdayaan terhadap kinerja karyawan.

Schneider et al. (1992) melaporkan bahwa keluaran psikologis karyawan secara keseluruhan, seperti kepuasan kerja, secara signifikan yang berkaitan dengan gairah organisasi untuk memberikan pelayanan prima. Dengan demikian, para peneliti meyakini bahwa orientasi layanan organisasional akan berhubungan positif dengan keluaran psikologis karyawan. Literatur ini mendukung keyakinan bahwa hal ini pada gilirannya akan secara positif terkait dengan kinerja karyawan, kepuasan pelanggan, persepsi nilai pelanggan, dan kinerja bisnis pada akhirnya, sebagaimana penelitian Yuniawan (2011) juga menunjukkan bahwa 
orientasi pelayanan mempengaruhi kinerja karyawan, maka dapat dibangun hipotesis ketiga H3o: Tidak terdapat pengaruh pada orientasi pelayanan terhadap kinerja karyawan. H3a: Terdapat pengaruh pada orientasi pelayanan terhadap kinerja karyawan. Sedangkan penghargaan mempengaruhi kinerja karyawan (Moorhead \& Griffin : 2013), hal ini didukung penelitian Hukubun, dkk. (2013) yang menyatakan penghargaan mempengaruhi kinerja karyawan, maka dapat dibangun hipotesis keempat: H4o: Tidak terdapat pengaruh pada orientasi pelayanan terhadap kinerja karyawan. H4a: Terdapat pengaruh pada orientasi pelayanan terhadap kinerja karyawan.

\section{Metode Penelitian}

Penelitian ini termasuk dalam penelitian field research dengan menggunakan pendekatan kuantitatif. Tipe penelitian ini adalah explanatory research atau penjelasan. Populasi dalam penelitian ini adalah semua karyawan di Bank Syariah Mandiri KC Salatiga. Karena jumlah populasi hanya 27 orang maka jumlah ini diambil semua sebagai sampel. Oleh sebab itu maka penentuan sampling menggunakan caraconvenience sampling atau biasa juga disebut dengan sampel jenuh. Convenience sampling dilakukan dengan cara memilih semua karyawan di Bank Syariah Mandiri KC Salatiga untuk menjadi responden tanpa syarat tertentu. Untuk menganalisis data hasil survey, menginterpretasi hasil penelitian maka digunakan teknik analisis regresi linear berganda, untuk mengetahui seberapa besar pengaruh pelatihan, pemberdayaan, orientasi pelayanan dan penghargaan terhadap kinerja karyawan. Teknik pengumpulan data dilakukan melalui kuesioner online. Skala pengukuran menggunakan skala Likert. Sumber data yang digunakan yaitu data primer yakni data yang diperoleh secara langsung melalui kuesioner dan data sekunder yang diperoleh dalam bentuk dokumen-dokumen.

\section{Table 1. Information on Demographic}

\begin{tabular}{lr}
\hline $\begin{array}{l}\text { Demographic } \\
\text { Gender }\end{array}$ & Percentage \\
\hline Pria & 63.0 \\
Wanita & 37.0
\end{tabular}




\section{Usia}

$20-25$

26-30

\section{Masa Kerja}

\begin{tabular}{lr}
1 tahun & 7.4 \\
2 tahun & 18.5 \\
3 tahun & 22.2 \\
6 tahun & 3.7 \\
7 tahun & 3.7 \\
8 tahun & 14.8 \\
9 tahun & 14.8 \\
10 tahun & 14.8 \\
\hline
\end{tabular}

Sumber : Hasil Olah Data Tahun 2020

Tabel 1 menunjukkan gambaran demografi responden yang diambil dalam penelitian ini.Tabel tersebut menyajikan bahwa jenis kelamin responden yang berpartisipasi dalam penelitian ini $63 \%$ adalah pria dan sisanya wanita 37\%. Responden berusia antara 20-25 sebanyak $18.5 \%$, usia 26-30 sebanyak 29.6\%, usia 31-35 sebanyak $18.5 \%$, usia 3640 sebanyak $22.2 \%$, dan usia $40-45$ sebanyak $11.1 \%$. Kemudian jika dilihat dari masa kerja responden cukup variatif dan didominasi oleh karyawan dengan masa kerja 3 tahun, sisanya dalam masa kerja 1 tahun 7.4\%, 2 tahun 18.5\%, 6 tahun 3.7\%, 7 tahun 3.7\%, 8 tahun $14.8 \%, 9$ tahun $14.8 \%$, dan masa kerja 10 tahun sebanyak $14.8 \%$.

Table 2. The Result of KMO and Bartlett of Sphericity

\begin{tabular}{lc}
\hline Testing & Value \\
\hline Sample Adequacy KMO & 0.708 \\
Bartlett of Sphericity & $0.000 *$ \\
\hline \multicolumn{2}{c}{$*$ significant at $\alpha<0.05$}
\end{tabular}

*significant at $\alpha<0.05$

Sumber : Hasil Olah Data Tahun 2021

Dari pengujian KMO and Bartlett test of sphericity dapat diketahui 
bahwa nilai KMO adalah sebesar 0.708 yang berarti nilai tersebut lebih baik. Sedangkan nilai Bartlett of Spherecity adalah sebesar 0.000 yang berarti hasil tes tersebut signifikan. Dari pengujian validitas juga dapat diketahui bahwa instrumen penelitian ini valid.

Table 3. Convergent Validity and Reliability Test

\begin{tabular}{|c|c|}
\hline Item & P-Correlation \\
\hline \multicolumn{2}{|c|}{ Pelatihan $(\mathrm{CR}=0.657) *$} \\
\hline PL1 & $0.812^{* *}$ \\
\hline PL2 & $0.784^{* *}$ \\
\hline PL3 & $0.737^{\text {** }}$ \\
\hline \multicolumn{2}{|c|}{ Pemberdayaan $(\mathrm{CR}=0.608) *$} \\
\hline PM1 & $0.816^{* *}$ \\
\hline PM2 & $0.690^{* * *}$ \\
\hline PM3 & $0.749^{* *}$ \\
\hline \multicolumn{2}{|c|}{ Orientasi Pelayanan $(\mathrm{CR}=\mathbf{0 . 7 9 9}) *$} \\
\hline OP1 & $0.615^{\text {** }}$ \\
\hline $\mathrm{OP} 2$ & $0.667^{\text {** }}$ \\
\hline OP3 & $0.554^{* *}$ \\
\hline \multicolumn{2}{|c|}{ Penghargaan $(\mathbf{C R}=0.799) *$} \\
\hline PH1 & $0.655^{* *}$ \\
\hline $\mathrm{PH} 2$ & $0.786^{* *}$ \\
\hline $\mathrm{PH} 3$ & $0.617^{* *}$ \\
\hline \multicolumn{2}{|c|}{ Kinerja Karyawan $(\mathbf{C R}=0.799) *$} \\
\hline KIN1 & $0.647^{* *}$ \\
\hline KIN2 & $0.656^{* *}$ \\
\hline KIN3 & $0.382^{\text {*** }}$ \\
\hline KIN4 & $0.564^{* * *}$ \\
\hline KIN5 & $0.472^{\text {*** }}$ \\
\hline
\end{tabular}

Sumber : Hasil Olah Data Tahun 2020

Tabel 3 menampilkan nilai uji reliabilitas instrumen dengan menunjukkan perhitungan nilai cronbach alpha.Dari perhitungan tersebut dapat diketahui bahwa nilai cronbach alpha untuk variabel pelatihan sebesar 0.657, variabel pemberdayaan sebesar 0.608, variabel orientasi pelayanan 0.799 , variabel penghargaan 0.799 , dan variabel kinerja 
karyawan sebesar 0.799.Dari nilai cronbach alpha yang melebihi 0.6 maka dapat disimpulkan instrumen penelitian reliabel. Selain itu semua indikator yang yang digunakan dalam penelitian ini adalah valid, terbukti nilai pearson correlation setiap indikator lebih besar dari nilai $r$ table 0.3809, kecuali indikator kinerja karyawan keempat (KIN4), maka indikator tersebut di droput dari penelitian ini.

\section{Hasil dan Pembahasan}

\section{Hasil}

Dari hasil pengujian hipotesis pertama (lihat table 4), didapatkan nilai $\mathrm{R}$ sebesar 0.285 , nilai $\mathrm{R}$ Square sebesar 0.081, dan nilai Adjusted $\mathrm{R}$ Square sebesar 0.044. Dari nilai R Square dapat diartikan bahwa hanya $8 \%$ variasi kinerja karyawan terbentuk oleh variabel pelatihan. Dengan kata lain, sebesar 92\% kinerja karyawan dibentuk oleh variabel lain selain pelatihan.

Pelatihan tidak memiliki pengaruh signifikan terhadap kinerja karyawan. Hal tersebut dapat dilihat dari hasil uji regresi sebesar 0.081, dengan nilai t hitung sebesar 1.484 dan nilai signifikansi 0.150 . Nilai signifikansi yang lebih besar dari 0.05 artinya dalam penelitian ini pelatihan yang diberikan oleh perusahaan tidak mempengaruhi tingkat kinerja karyawan.

Selanjutnya dari hasil pengujian hipotesis kedua, didapatkan nilai $\mathrm{R}$ sebesar 0.275, nilai $\mathrm{R}$ Square sebesar 0.076, dan nilai Adjusted R Square sebesar 0.039. Dari nilai $\mathrm{R}$ Square dapat diartikan bahwa hanya $7 \%$ variasi kinerja karyawan terbentuk oleh variabel pemberdayaan. Dengan kata lain, sebesar 93\% kinerja karyawan dibentuk oleh variabel lain selain pemberdayaan.

Pemberdayaan juga tidak memiliki pengaruh signifikan terhadap kinerja karyawan. Hal tersebut dapat dilihat dari hasil uji regresi sebesar 0.076, dengan nilai t hitung sebesar 1.432 dan nilai signifikansi 0.165 . Nilai signifikansi yang lebih besar dari 0.05 artinya dalam penelitian ini pemberdayaan yang diberikan oleh perusahaan tidak mempengaruhi tingkat kinerja karyawan.

Kemudian hasil pengujian hipotesis ketiga didapatkan nilai $\mathrm{R}$ sebesar 0.478, nilai R Square sebesar 0.288, dan nilai Adjusted R Square sebesar 0.197.Dari nilai R Square dapat diartikan bahwa 29\% variasi kinerja karyawan dibentuk oleh variabel orientasi pelanggan. Dengan kata 
lain, sebesar $71 \%$ kinerja karyawan dibentuk oleh variabel lain selain orientasi pelanggan.

Orientasi pelanggan memiliki pengaruh positif dan signifikan terhadap kinerja karyawan. Hal tersebut dapat dilihat dari hasil uji regresi sebesar 0.288 , dengan nilai t hitung sebesar 2.717 dan nilai signifikansi 0.012. Nilai signifikansi yang lebih kecil dari 0.05 artinya jika orientasi pelanggan ditingkatkan, maka kinerja karyawan semakin meningkat pula.

Tabel 4. Hasil Pengujian Direct Effect Determinant Coefficient and Adjusted R Square, Uji t, dan Uji F

\begin{tabular}{lcccc}
\hline $\begin{array}{l}\text { Determinant Coefficient \& } \\
\text { Adjusted R }\end{array}$ & $\mathbf{P L} \rightarrow \mathbf{K I N}$ & $\mathbf{P M} \rightarrow \mathbf{K I N}$ & $\mathbf{O P} \rightarrow \mathbf{K I}$ & $\mathbf{P H} \rightarrow \mathbf{K I}$ \\
\hline $\mathrm{R}$ & 0.285 & 0.275 & 0.478 & $\mathbf{N}$ \\
R2 & 0.081 & 0.076 & 0.288 & 0.611 \\
Adjusted R Square & 0.044 & 0.039 & 0.197 & 0.348 \\
Standardized & & & & \\
Coefficient Beta & & & & \\
T & 1.484 & 1.432 & 2.717 & 3.855 \\
Sig. & 0.150 & 0.165 & 0.012 & 0.001 \\
Result of F test & & & & \\
F & 2.203 & 2.050 & 7.384 & 14.860 \\
Sig. & 0.150 & 0.165 & 0.012 & 0.001 \\
\hline
\end{tabular}

*Significance (Sig.<0.05)

Sumber: Hasil Olah Data Tahun 2021

Terakhir, hasil pengujian hipotesis keempat didapatkan nilai $\mathrm{R}$ sebesar 0.611, nilai R Square sebesar 0.373, dan nilai Adjusted R Square sebesar 0.348. Dari nilai R Square dapat diartikan bahwa $37 \%$ variasi kinerja karyawan dibentuk oleh variabel penghargaan. Dengan kata lain, sebesar $63 \%$ kinerja karyawan dibentuk oleh variabel lain selain penghargaan.

Penghargaan memiliki pengaruh positif dan signifikan terhadap kinerja karyawan. Hal tersebut dapat dilihat dari hasil uji regresi sebesar 0.373 , dengan nilai t hitung sebesar 3.855 dan nilai signifikansi 0.001 . Nilai signifikansi yang lebih kecil dari 0.05 artinya jika penghargaan yang diberikan perusahaan semakin bernilai bagi karyawan, maka kinerja 
karyawan akan meningkat.

\section{Pembahasan}

Di dalam strategi pengelolaan sumber daya manusia terdapat variabel-variabel seperti pelatihan, pemberdayaan, orientasi pelayanan dan peghargaan. Variabel-variabel ini diprediksi mampu memberikan pengaruh terhadap kinerja karyawan. Namun ternyata tidak semua demikian. Dalam penelitian ini ternyata variabel pelatihan dan pemberdayaan tidak memiliki pengaruh yang signifikan terhadap kinerja karyawan. Hal ini bertentangan dengan hasil penelitian Denny Triasmoko, Moch. Djudi Mukzam, Gunawan Eko Nurtjahjono (2014) yang hasilnya pelatihan berpengaruh secara signifikan terhadap kinerja karyawan dan hasil penelitian Putu Chori Suryadewi, I Ketut Dunia, Naswan Suharsono (2014) yang hasilnya terdapat pengaruh positif pemberdayaan terhadap kinerja karyawan. Tetapi hasil penelitian ini mendukung hasil penelitian yang dilakukan oleh Felisita (2016) yaitu pelatihan tidak berpengaruh secara positif terhadap kinerja karyawan.

Sementara itu dalam penelitian ini, dua variabel yang lain yaitu orientasi pelayanan dan penghargaan memiliki pengaruh positif dan signifikan terhadap kinerja karyawan. Hal ini bertentangan dengan hasil penelitian yang dilakukan oleh Felisita (2016) yaitu penghargaan (kompensasi) tidak berpengaruh secara positif terhadap kinerja karyawan. Tetapi hasil ini mendukung hasil penelitian Ahyar Yuniawan (2011) yang menyatakan bahwa orientasi layanan meningkatkan kinerja bisnis dan hasil penelitian Deanly M. Hukubun, William A. Areros, Ventje Tatimu (2013) yang mengemukakan bahwa penghargaan berpengaruh secara positif dan signifikan terhadap kinerja.

\section{Simpulan}

Untuk membentuk kinerja karyawan dapat dibangun dengan melihat beberapa komponen seperti pelatihan, pemberdayaan, orientasi pelayanan, dan penghargaan yang diberikan. Dalam penelitian ini pelatihan dan pemberdayaan tidak memiliki pengaruh terhadap kinerja karyawan. Sedangkan orientasi pelayanan dan penghargaan justru berpengaruh positif dan signifikan terhadap kinerja karyawan. Kinerja karyawan yang dikelola dengan baik akan menjadi prediktor yang kuat dalam perilaku karyawan pada lembaga bisnis syariah. 


\section{Daftar Pustaka}

Bakar, A., Raida, et al. (2008). How We Do Things Around Here: Implications of Corporate Culture on Job Performance. The Business Review, Cambridge, Vol. 9, No.2.

Adhinugroho., Wibowo, E. (2015). Praktek Pengelolan Sumber Daya Manusia Terhadap Kinerja Pelayanan Melalui Kepuasan Kerja pada maskapai Penerbangan Komersial di Indonesia.Jurnal Manajemen dan Pemasaran Jasa, Vol.8, No.2.

Deanly M. H, et al. (2013). Pengaruh Penghargaan (Reward) Terhadap Kinerja Karyawan Best Western Lagoon Manado.E-Jurnal Adminstrasi Bisnis Universitas Sam Ratulangi, hal.84-88.

Dessler, G. (2010). Manajemen Sumber Daya Manusia. Edisi Kesepuluh. Jakarta Barat: PT Indeks.

Edirisooriya, W.A. (2014). Impact of Rewards on Employee Performance: with Special Reference to ElctriCo.International Conference on Management and Economics.

Felisita. (2016). Pengaruh Pelatihan, Pengembangan, Kompensasi dan Motivasi Terhadap Kinerja Karyawan (Studi Kasus pada Karyawan Administrasi Universitas Sanata Dharma Yogyakarta). Skripsi. Fakultas Ekonomi Program Studi Manajemen.

Hasibuan, M. Sp. (2012). Manajemen Sumber Daya Manusia. Edisi Revisi, Cetakan KeTiga Belas. Jakarta: Bumi Aksara.

Mahardiani. (2004). Faktor-faktor Yang Berpengaruh Terhadap Pemberdayaan Karyawan di RS Roemani Semarang. Tesis. Semarang: Program Pascasarjana UNDIP.

Mangkunegara.,Prabu, A. (2009). Manajemen Sumber Daya Manusia Perusahaan. Edisi Kesembilan. Bandung: PT Remaja Rosdakarya.

Mondy, R. W. (2008). Human Resource Management. Di alih bahasa oleh Bayu Airlangga, M.M. Edisi Kesepuluh.PT Gelora Aksara Pratama.

Rod, et al. (2010). Management Commitment to Service Recovery Performance: A Study of Frontline Employeesn in Public and Private Hospitalsin New Zealand. International Journal of Pharmaceutical an Healthcare Marketing, Vol.4, No.1. 
Sadili, S. (2010). Manajemen Sumber Daya Manusia. Bandung: Pustaka Setia.

Sajuyigbe, A. S., et al. (2013). Impact of Reward On Employees Performance In A SelectedManufacturing Companies InIbadan, Oyo State, Nigeria. International Journal of Arts and Commerce. Vol. 2 (2): pp 27-32.

Schneider, et al. (1992). "A Framework for Analyzing Customer Service Organizations in Manufacturing", Academy of Management Review, page 75-95.

Sedarmayanti. (2007). Manajemen Sumber Daya Manusia Reformasi Birokrasi dan Manajemen Pegawai Negeri Sipil. Badung: Refika Aditama.

Simamora, H. (1999). Manajemen Sumber Daya Manusia. Edisi Kedua. Yogyakarta. STIE YKPN.

Snell, et al. (2010). Principles of Human Resource. Management,15th ed. Mason, OH: South Western - Cengage Learning.

Suryadewi, et al. (2014). Pengaruh Pemberdayaan Karyawan Terhadap

Kinerja Karyawan Pada PT. Bali Segara Nusantara.Jurnal Pendidikan Ekonomi UDIKSHA Vol: 4 No: 1 Hal.1-11.

Triasmoko, et al; Gunawan Eko Nurtjahjono. (2014). Pengaruh Pelatihan Kerja Terhadap Kinerja Karyawan, Penelitian pada Karyawan PT Pos Indonesia (Persero) Cabang Kota Kediri. Jurnal Administrasi Bisnis (JAB)|Vol. 12 No. 1 Juli 2014 Hal.1-10.

Wibowo. (2007). Manajemen Kinerja. Yogyakarta: PT. Raja Grafindo Persada.

Wirawan. (2009). Evaluasi Kinerja Sumber DayaManusia. Edisi Pertama. Jakarta: Salemba Empat

Yuniawan, A. (2011). Evaluasi Orientasi Layanan Sebagai Bagian dari Budaya Organisasi dan Efeknya Terhadap Kinerja Organisasi. Jurnal Manajemen dan Kewirausahaan. Vol.13, No.1, Maret 2011: 46-60.

Masriadi (2019). Kasus Pencurian di Bank Syariah Mandiri Terungkap, Pelakunya Karyawan Sendiri. Retrieved from https://regional.kompas.com/read/2019/07/01/08170921/kasuspencurian-di-bank-syariah-mandiri-terungkap-pelakunya-karyawansendiri. 
